\title{
The Quest for Identity and Self-Determination in the SNNP Region of Ethiopia
}

\author{
Beza Dessalegn* and Nigussie Afesha**
}

\begin{abstract}
The rich ethnic diversity in the SNNP region is being managed by different mechanisms of constitutional, institutional, and political practice. Yet, this has not been able to contain new questions of identity, not only seeking for recognition as a distinct ethnic group, but also a desire to establish ethnic territorial administrations. Moreover, ethnic groups that are already recognized are also laying claims to various self-determination rights, inter alia, to territorial autonomy, equitable participation, and the redrawing of internal (ethnic) boundaries. Based on legal analysis of cases from the SNNP region, the article critically discusses the quest for identity and self-determination, and provides an overview of the experience of the region. In dealing with the existing dilemma, we argue that there is a need to maintain the balance between constitutional rights to identity recognition and self-determination with the threat of ethnic and territorial fragmentations.
\end{abstract}

\section{Key terms}

Identity $\cdot$ Self-determination $\cdot$ Federalism $\cdot$ Ethnic groups $\cdot$ SNNP region

DOI http://dx.doi.org/10.4314/mlr.v13i1.3

This article is licensed under a Creative Commons Attribution-NonCommercial-

NoDerivs (CC BY-NC-ND)

\section{Introduction}

The Southern Nations Nationalities and Peoples (SNNP) region attests to the extremes of Ethiopia's ethnic federal experiment. On the one hand, the region, on the basis of a carefully crafted constitutional architecture and an overarching political practice, tries to accommodate its Nations, Nationalities and Peoples (NNP) by empowering them to preserve their identities and manage their own

\footnotetext{
* Beza Dessalegn: LLB, LLM, PhD, Assistant Professor, College of Law and Governance, School of Law, Hawassa University. Email: bezadesy4722@gmail.com

** Nigussie Afesha: LLB, MA, Associate Professor, College of Law and Governance, School of Law, Hawassa University. Email: nigussie.afesha12@gmail.com
} 
affairs in defined territories. On the other hand, it stands at crossroads when it comes to adequately responding to the ever increasing questions, which inter alia include identity, equitable participation and self-rule claims by various ethnic groups. The latter claim, in particular, has unleashed what some, from the outset, had feared that ethnic federalism would trigger ethnic fragmentations and a never-ending request for ethnic territorial homelands. ${ }^{1}$

In tandem with the overall logic of Ethiopia's version of federalism, the region has identified some 56 ethnic groups ${ }^{2}$ as its native (indigenous) identities capable of exercising the benefits accruing from the federal formula -be it in the form of territorial autonomy (TA), political participation, or cultural, linguistic, and economic self-determination (SD). Nonetheless, current developments show that the region has disappointed many when it comes to responding to the quest for identity and self-government rights. ${ }^{3}$

At the moment, several communities are pushing for the recognition of their distinct identity in addition to the already existing 56 native identities, while the already recognized ethnic groups - dissatisfied with their status quo- are laying various claims to new zones and liyu weredas, territorial re-demarcations in order to be united with their ethnic kin across (territorial and political) borders, and equitable participation in the territories they already reside.

A strong caveat to be noted is that most of the research in this article is based on developments before the political upheaval taking place since early 2018 . While the SNNP region remained relatively calm during anti-government protests, it has however endured some of the worst inter communal violence after the coming to power of a new Prime Minister. Some of the instances

\footnotetext{
Frequently used acronyms:

CCI Council of Constitutional Inquiry

CoN Council of Nationalities

HoF House of Federation

SD Self determination

SNNP Southern Nations, Nationalities and Peoples

${ }^{1}$ Minase Haile (1996). "The New Ethiopian Constitution: Its Impact upon Unity, Human Rights and Development" Suffolk Transnational Law Review, Vol. 20, No.1. , pp. 20-21.

${ }^{2}$ For the list of the 56 ethnic groups, see the document released by the Southern Nations Nationalities and Peoples Regional State Council of Nationalities, Communication, Minutes and Documentation Supporting Core Process Unit, (November 2011), document on file. This document additionally identifies, which of these ethnic groups are considered native to which of the zones and special woredas (district) - impliedly designating their ethnic territorial homelands. Yet, in order to fully understand the overall status of each of these ethnic groups at the regional and sub-regional administrations, one has to carefully study the political practice, which has far reaching implications, at times, over and above the constitutional design.

${ }^{3}$ See the discussions below under sections 2 and 3 .
} 
include the regional capital Hawassa and surrounding areas in Sidama zone that saw the worst violence against non-indigenes. Protests in the towns of Wolaita Soddo and Wolkite, where property was ransacked and lives were lost and hundreds of thousands of ethnic Gedeo displaced by ethnic violence from the region of Oromia.

Although the government has, in principle, agreed to answer the unfolding claims, the region currently, facing a serious threat of disintegration, remains under a military lockdown. While there are strong indications that the developing situations exemplify strong tendencies of ethnic and territorial fragmentations, this article neither provides a summary of these events nor does it base itself on these still ongoing issues, as this is not the place to do so.

The following section, i.e., Section 1 forwards a conceptual framework for understanding the nature and types of ethnic and territorial claims under ethnic federalism. In the second section, the region's historical as well as political antecedents leading to distinct identity and SD claims are examined. Afterwards, the constitutional and legal frameworks that are used as springboards to decide on identity and SD claims are investigated by examining the various petitions. In the third and fourth sections, discussion is made on whether the existing legal framework is adequate in responding to the various demands or not, and in view of that, the article examines the sufficiency of the responses given so far and what can be done to balance identity and SD claims with the threats of ethnic and territorial fragmentations.

\section{Ethnic and Territorial Claims under Ethnic Federalism}

In simple terms, ethnic federalism is a type of federalism, which makes the constituent units of a federation, or at least some of them, homelands controlled by designated ethnic communities. ${ }^{4}$ To be exact, under ethnic federalism regional borders are intentionally drawn in favor of an ethnic group in order for the group to become a numerical and political majority. As such, Ethiopia's unique and enigmatic constitutional experiment in ethnic federalism -by allocating ethnic homelands to select ethnic groups and bolstered by the right to self-determination up to and including secession- has had a significant impact on the territorial and ethnic reorganization of the state since 1991.

By making ethnic groups the subject of all the rights and privileges, ethnic federalism in Ethiopia has elevated ethnic communities to the position of

\footnotetext{
${ }^{4}$ Philip G. Roeder (2010). 'Ethno federalism and the Mismanagement of Conflicting Nationalisms', in Jan Erk and Lawrence M. Anderson (eds.), The Paradox of Federalism: Does Self-Rule Accommodate or Exacerbate Ethnic Divisions? Routledge, p. 14.
} 
'makers and breakers' of the arrangement itself.' The argument that ethnic federalism -in a bid to receive the greater share of benefit ${ }^{6}$ - encourages divisions between and among ethnic communities has long been confirmed. ${ }^{7}$ Inevitably, federalism exclusively founded upon ethnicity encourages ethnic communities to seek for greater autonomy including secession. ${ }^{8}$

Obviously, under a political and constitutional configuration in which ethnic groups are accorded a special status and the benefits that go with it, claims based on ethnic identity will not only proliferate, but will also be contested by those who correspondingly stand to lose from it. As rightly noted by Roeder:

"ethno federal and autonomy arrangements in ethnically divided societies structure politics inside ethnic communities, among ethnic communities and between those ethnic communities and the central government in ways that bring political instability. These institutions privilege some identities and interests and distribute coercive and defensive capabilities in a way that increases the likelihood of escalation of conflict into acute nation-state crises. Thus, these institutional arrangements are more likely than simple federal or unitary institutions to empower ethnic entrepreneurs who threaten the peace, the survival of democracy and the unity of the state. Particularly after civil wars, ethno federalism and autonomy arrangements represent imprudent institutional choices." $" 9$

The Ethiopian dispensation, not only has empowered (selected) ethnic communities in ethnically defined territories, but has also permitted (the remaining) ethnic groups to seek and determine their own ethnic territorial spaces. ${ }^{10}$ Paradoxically, the government, contrary to constitutional stipulations, has maintained a tight grip on those demanding their own territories -apparently, giving with one hand and taking it away with the other. ${ }^{11}$ Probabaly, in offering constitutional authorization to territorial claims, the setup, has not anticipated the possible formation of new ethnic groups seeking recognition or break up of existing ethnic communities, which eventually demand new ethnic territorial

\footnotetext{
${ }^{5}$ Yonatan Tesfaye Fessha (2017). "The Original Sin of Ethiopian Federalism", Ethnopolitics, Vol.16, No.3, pp. 232-245.

${ }^{6}$ Solomon Negussie (2008). Fiscal Federalism in the Ethiopian Ethnic-based Federal System, Forum of Federations, p. 261.

7 Philip G. Roeder (2009). "Ethnofederalism and the Mismanagement of Conflicting Nationalisms" Regional \& Federal Studies, Vol. 19, No.2, pp. 204-206.

${ }^{8}$ Ted Robert Gurr (2000). Peoples versus States: Minorities at Risk in the New Century. Washington. DC: United States Institute of Peace Press, p. 195.

${ }^{9}$ Roeder (2009), supra note 7, p. 206.

${ }^{10}$ See, the FDRE Constitution, Arts 39 and 47.

${ }^{11}$ Lovise Aalen (2011). The Politics of Ethnicity in Ethiopia: Actors, Power and Mobilization under Ethnic Federalism, Brill: Martinus Nijhof, p. 106.
} 
homelands. However, the question of claiming ethnic difference and hence a renegotiation of a new identity became so common that it is threatening the legal and political order of the federation.

But it cannot also be claimed that all this was unprecedented. The FDRE Constitution (which is authored by the NNPs) creates a 'legal fiction' -that the country is the sum of its constituent ethnic groups, all sovereign power resides in them, they are entitled to own ethnically defined regions and sub-regional administrations, and, according to the second sentence in Article 40(3) of the Constitution, land is "the common property of the Nations, Nationalities and Peoples of Ethiopia." The tendency to create, harden and institutionalize difference along ethnic contours ${ }^{12}$ was thus clearly visible from the outset. Moreover, the acknowledgment of ethnicity as the sole organizing identity, made recognition as a distinct ethnic group, the only way to be part of the federal dispensation and access the benefits accruing from it. ${ }^{13}$

Ethnic federalism in Ethiopia was made a first choice to respond to the long overdue demands of ethnic groups for equality of treatment, political and territorial autonomy as well as redressing of past injustices. ${ }^{14}$ And yet, after more than two decades of experimentation, it has exacerbated the very problems it was supposed to eradicate by localizing ethnic conflicts. ${ }^{15}$ By territorializing ethnicities into regional and sub-regional boundaries, it also gave rise to new minorities that, by and large, have been treated unfairly by regional and subregional majorities. These minorities had no option but to intensify their claims for SD - seeking new territorial homelands - believing territorial autonomy is the only way to reverse their current status of marginalization. ${ }^{16}$ This has resulted, as further explained in the next section, in vicious cycles of identity and SD claims, which the territorialization of ethnicities does not seem to have an answer for.

\footnotetext{
${ }^{12}$ Jan Erk and Lawrence Anderson (2010). 'The Paradox of Federalism: Does Self-Rule Accommodate or Exacerbate Ethnic Divisions?' in Jan Erk and Lawrence M. Anderson, The Paradox of Federalism: Does Self-Rule Accommodate or Exacerbate Ethnic Divisions? Routledge, p. 2.

${ }^{13}$ Yonatan, The Original Sin, supra note 7, p. 232.

${ }^{14}$ See generally, See Andreas Eshete (2013) "Ethnic Federalism: New Frontiers in Ethiopian Politics" in First National Conference on Federalism, Conflict and Peace Building, Addis Ababa: United Printers, pp. 142- 172.

${ }^{15}$ Asnake Kefale, (2009). Federalism and Ethnic Conflict in Ethiopia: A Comparative study of the Somali and Benishangul-Gumuz Regions, (PHD Thesis, University of Leiden) p. 6.

${ }^{16}$ See the discussion in Sections $2 \mathrm{ff}$.
} 


\section{Historical and Political Context vis-à-vis Identity and Self- Determination Claims}

During the transitional period (1991-1994), the region that is currently designated as SNNP existed as five separate regions - named as Regions (Kilils) Seven, Eight, Nine, Ten and Eleven. ${ }^{17}$ At the time, Proclamation No 7/1992 recognized 45 ethnic groups as the native identities of these regions. However, since then, and after the merger of the five regions into one, the number of the officially recognized native identities has increased to 56. Ethnically defined groups within the new dispensation had to therefore be accommodated through sub-regional administrations known as zones and liyu weredas. Of course, the regional constitution, in an institutionalization to an integrationist approach, obliged the Council of Nationalities $(\mathrm{CoN})$ to promote and consolidate the unity of the region. ${ }^{18}$

Because the region is further divided into ethnic based zones and liyu woredas, the sub regional structures exhibit a number of variations when it comes to identity and SD claims. Some zones like South Omo and Segene are institutionally setup as multiethnic, and hence they are entangled with competitive demands of both identity and SD between and among the several indigenous groups. However, Gurage Zone embraces other indigenous minorities although the name indicates a particular ethnic group, and this has brought the desire to further establish distinct ethnically defined zones and liyu woredas by these indigenous minorities. The zone also is rattled with claims of new identity questions as groups continue to lay claims in order to breakaway from Gurage - their supposed parent ethnic group. ${ }^{19}$ On top of this, in the context of internal border disputes, as is the case between Wolayita and Sidama, the region harbors one of the most critical territorial disputes in the country.

Politically speaking, during the early days of federalism, EPRDF has focused on administrative integration, especially in the SNNP region, despite its commitment and permission to ethnic groups to organize and mobilize independently. ${ }^{20}$ However, the region that is currently organized under 20 ethnically defined local governments is clearly struggling with accommodating 56 ethnic groups. It was due to this struggle that the number and identity of the local government structures been a subject of various reformulations. In what became a stern test to the region's identity claims, Silte ethnic group broke away

\footnotetext{
${ }^{17}$ See, Proc. 7/1992, Art. 3(1).

${ }^{18}$ See, the SNNP Constitution, Art. 59(4).

${ }^{19}$ For a discussion into the Silte case, see Lara Smith (2007). "Voting for an Ethnic Identity: Procedural and Institutional Responses to Ethnic Conflict in Ethiopia", Journal of Modern African Studies, Vol.45 No. 4, pp. 565-594.

${ }^{20}$ Aalen, supra note 11, pp. 98-99.
} 
from the Gurage and not only established itself as distinct, but also acquired a local government structure of its own -the Silte zone. Moreover, recognized ethnic groups have also continued to lay claim to various ethnic rights. For instance, during the initial days, North Omo zone was partitioned between Wolayita, Dawro, Gamo, Gofa and Basketo. In the year 2011, the liyu woredas of Konso, Burji, Derashe and Amaro were merged together as Segene, while by the year 2018 Gamo-Gofa zone was broken into Gamo and Gofa. Alaba was 'elevated' to a zone from a liyu wereda and Konso managed to break away from the Segene zone to become a zone in its own. As the recent decision of the regional council indicates, these measures were supposedly undertaken to respond to the growing ethnic based demands within the region. ${ }^{21}$

At the moment, the region is exhibiting a strong tendency to disintegrate. A handful of ethnic groups have already submitted their desire to form independent regions, ${ }^{22}$ while others are pushing for sub-regional administrations of their own. ${ }^{23}$ Many are carefully watching the claim by the Sidama for a regional status and its outcome, as it will surely decide the future fate of the region.

\section{Identity and Self-determination Claims}

Ethnic identity and, importantly, the ensuing SD rights, which follow from recognizing one as a distinct ethnic group, arguably, are the two pillars of Ethiopia's experiment on ethnic federalism. In particular, these two elements have far reaching implications in the SNNP region where many groups feel that their identity and SD rights have been tampered with. ${ }^{24}$ Legally speaking, the federal constitution, SNNP region's revised constitution and subordinate federal as well as SNNP region's legislations (proclamations) provide for the constitutional and legal frameworks on how issues of separate identity and SD are managed. A closer look at these laws reveals that they stipulate for procedural as well as substantive requirements, claimants (claiming either for distinct identity recognition, SD, or both) are supposed to comply with. The following two sub-sections discuss these matters in some detail.

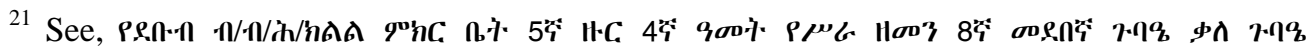
document on file.

${ }^{22}$ Sidama, Kefa, Wolayita, Hadiaya and Gurage are among the NNPs who have pressed their demand openly for independent regional states, although the Sidama has gone additional steps, ahead of the others. The Sidama nation referred their claim to the SNNP regional state council, and the state council accepting their plea has referred the matter to the National Electoral Board for the later to organize a referendum on the new region formation request.

${ }^{23}$ Developments in Gurage and Bench-Maji zones attest to this fact.

${ }^{24}$ See the discussions below. 


\subsection{Distinct identity recognition claims}

Unlike issues relating to $\mathrm{SD},{ }^{25}$ where extensive provisions appear both in the federal as well as regional constitutions and subordinate legislations, the major challenge in resolving identity questions was the absence of a clear-cut law, which explicitly addressed a group's claim to be recognized as a distinct NNP. ${ }^{26}$ In view of such fact, one has to trace the framework for analysis primarily from the House of Federation's (HoF $)^{27}$ decision on the Silte case.

In responding to the Silte identity question - the first of its kind in distinct identity recognition claims - the HoF (together with the advisory opinion from the Council of Constitutional Inquiry $(\mathrm{CCI})^{28}$ ) substantively relied on Article 39(5) of the federal Constitution. It argued that communities who claim distinct identity recognition are required to show that they have their own language, culture, belief in a common or related identity (self-identification), psychological makeup, and territorial contiguity. Concerning these requirements, the Council of Nationalities (CoN) -mandated with the power of settling identity determination issues at the regional level- in one of its decisions regarding identity determination underscored that a claimant community does not need to fulfill all the five criteria cumulatively. ${ }^{29}$ However, the $\mathrm{CoN}$ has since changed this position and the current understanding is that these are cumulative standards necessary for analyzing and deciding on identity determination claims. ${ }^{30}$

An examination of the identity determination petitions from the three zones of Gamo-Gofa, South Omo and Gurage reveal that, although all claim to have fulfilled the foregoing requirements, they tend to emphasize on one of the elements to justify their distinctness. For instance, the Welene community, which is fiercely struggling to separate itself from the Gurage identity in the Gurage zone, ${ }^{31}$ claims that they are wrongly characterized as Gurage. ${ }^{32}$ Welenes

${ }^{25}$ See the discussion below under section 3.2.

${ }^{26}$ See the House of the Federation of the Federal Democratic Republic of Ethiopia "Advisory opinion of the CCI on the Silte case" (2008). Journal of Constitutional Decisions, Vol. 1, pp. 42-43.

${ }^{27}$ The HoF is the second house of parliament, composed of the recognized NNPs, entrusted with various unique powers, among which, the power to interpret the constitution stands out as the prominent one. See the FDRE Constitution, Art. 62(1).

${ }^{28}$ The CCI is an advisory body advising the HoF on issue of constitutional interpretation. See, the FDRE Constitution, Art. 84.

29 This was the position of the $\mathrm{CoN}$ in deliberating on the Manja identity recognition petition. Christophe Van der Beken (2012). Unity in Diversity-Federalism as a Mechanism to Accommodate Ethnic Diversity: The Case of Ethiopia, Lit Verlag, p. 274.

${ }^{30}$ Interview with Speaker of the House of the Council of Nationalities, SNNP Regional State (Hawassa, 12 July 2017).

31 Application by Welene community to the CoN, (10/11/2005 E.C), (Tir 02, 2007 E.C), (Hidar 11, 2005 E.C), (Meskerem 9, 2003), on file with the registrar of the CoN, Hawassa; 
argue that they possess the distinct identity markers provided in both the federal and SNNP constitution. ${ }^{33}$ However, as their several petitions illustrate, Welenes strongly argue for a separate identity singularly on the basis of their distinct language from the Gurage.

In Gamo Gofa zone, ${ }^{34}$ Dorze $^{35}$ and Qucha ${ }^{36}$ are petitioning to negotiate their distinctness from Gamo ethnic group, while Mello ${ }^{37}$ and Uba Gezo ${ }^{38}$ wish to separate from Gofa ethnic group. What differentiate distinct identity determination issues of the zone from that of the Welene is the mutual intelligibility of languages between petitioner communities and their respective parent ethnic groups from which separation is sought.

Another identity determination from this zone relates to the Seyk Ari (which border the Ari of the South-Omo). ${ }^{39}$ They are disenfranchised due to their demarcation into Gamo-Gofa zone, which broke them apart from their ethnic kin Aris in South-Omo, and they have thus instituted an identity recognition claim. ${ }^{40}$ A closer examination of the Seik Ari petition, however, demonstrates that their demand, rather than being recognized as a distinct ethnic group, is more of requesting participatory rights within the Gamo-Gofa zone or re-demarcation

Application by the Welene Peoples Democratic Party to the CoN, (Tahsas 4, 2008), on file with the registrar of the CoN, Hawassa.

32 Application submitted by Welene people to the CoN, (10/11/2005 E.C), on file with the registrar of the CoN, Hawassa; see also the application by the Wolene Language speakers' people democratic Moment (currently named, the Welene People Democratic Party (WPDT), letter written to the CoN on 26/02/2001 E.C., document on the file with the registrar of the CoN, Hawassa.

${ }^{33}$ Application submitted by Welene people to the CoN, Ibid.

34 This zone is one among those institutionally established as multiethnic. Gamo, Gofa, Oyida, Zayisse, and Gidecho ethnic groups are identified as the native identities of the zone.

${ }^{35}$ Application of the Dorze to the CoN, (Hidar 11, 2004 E.C), on file with the registrar of the CoN, Hawassa.

${ }^{36}$ Application of the Qucha to the CoN, (Nehase 29, 2005 E.C) on file with the registrar of the CoN, Hawassa.

${ }^{37}$ Minutes of the Mello-Koza woreda, 3rd round second regular meeting, (22/6/98 E.C), on file with the registrar of the CoN, Hawassa. Interestingly, the Mello-Koza woreda council has renounced the demand of the Gofa for a zonal status. The motive behind it seems very clear. If Gofas are allowed a zonal status, Mellos will be subjected to additional discrimination and marginalization than what is already in existence.

${ }^{38}$ Uba Gezo petition to the CoN (20/04/2005 E.C), on file with the registrar of the CoN, Hawassa.

39 Application of the Seyik Ari to the CoN, (21/05/2001 E.C), (24/09/2001 E.C), (8/01/05 E.C), (4/02/2005 E.C), (22/10/2005 E.C), on file with the registrar of the CoN, Hawassa.

${ }^{40}$ Ibid. 
into their ethnic kin found in South Omo zone. Probably, the request for distinct recognition is triggered by the lack of participatory rights within the zone.

In the South Omo zone, the Goza Zift community ${ }^{41}$ in petitioning for identity determination, argued how its language differs from the remaining ethnic groups by citing selected vocabularies, their equivalents in Amharic (the working language of the federal as well as the SNNP regional governments) and their variations with other NNPs languages ${ }^{42}$ and indicated how their culture is unrelated to the remaining NNPs by referring to their customary marriage celebration, funeral ceremonies, and historical legacies. ${ }^{43}$ Yet, the major point for them in seeking identity determination seems to relate to ensuring their survival and the creation of a conducive environment to develop their language, culture and preserve their history, which are all on the verge of extinction. All these claims have not been given formal response by the regional apparatus.

With regard to the question as to who has the authority to decide on identity questions, the opinion by the majority members of the Council of Constitutional Inquiry (CCI) -which was later on fully endorsed by the HoF- ${ }^{44}$ stated that Articles 52(2)(a) and 62(3) of the FDRE Constitution do not clearly mention the entity that has the power to answer identity questions. Based on this premise, the CCI stated that such matters shall be interpreted as falling under the (residual) powers of the regions. ${ }^{45}$

In justifying the argument, the CCI stated that regions have to first answer the question of identity in order to establish the necessary institutions for self-rule impliedly making identity questions within their jurisdiction. Secondly, as questions of identity are initially raised in the regions, responding to identity claims is the power of the regional councils because the regions have exclusive jurisdiction on regional matters in accordance with the FDRE Constitution). ${ }^{46}$

${ }^{41}$ Application submitted by Goza Zift community to the CoN, (24/12/2002 E.C), on file with the registrar of the CoN, Hawassa.

${ }^{42}$ Ibid.

${ }^{43}$ Ibid.

${ }^{44}$ Decision of the House of the Federation Regarding Resolution of Claim For Identity, (April 2001), document on file.

${ }^{45}$ CCI advisory opinion, supra note 26, p. 44.

${ }^{46}$ It seems, the reference to the regional councils was because, at the time, the power to interpret regional constitutions was vested with the respective regional councils. It was only after the regions revised their constitutions in and after 2001 that they conferred the power to interpret the regional constitutions on a separate regional organ - the Constitutional Interpretation Commission (CIC)). The SNNP region, however, entrusted the same task to the $\mathrm{CoN}$ - an institution similar to that of the HoF. 
Yet, a party aggrieved by the decisions of regional councils has the right to appeal to the HoF. ${ }^{47}$

The CCI cautiously elaborated on the power of the regional councils by stating that despite the role played by the councils, the ultimate decision maker in identity questions is the concerned community itself. ${ }^{48}$ The primary role of the regional councils is to check whether the requirements set under Article 39(5) have been (procedurally) complied with. If the claimant community or group proves that there is a sufficient case, the regional council causes a referendum to be organized and the concerned community decides on the final fate of the identity question via direct participation. ${ }^{49}$

Regarding procedural matters (like who shall be a claimant in identity recognition claims), the HoF stated that there is no restriction by the Constitution as to who has standing. Yet, claimants are still required to submit their questions in writing by showing that the requirements specified under Article 39(5) of the Constitution are satisfied. The concerned regional council can afterwards make further inquiries on whether the elements Article 39(5) have been fulfilled or not. The HoF decision highlighted that the question of identity shall be ripe for a referendum within a maximum period of one year from the date of submission of the claim to the concerned regional council. ${ }^{50}$

${ }^{47}$ The power of the HoF to decide on such matters emanates from art 62(3) of the FDRE Constitution. See also CCI advisory opinion, supra note 26, p. 44; As the HoF decision stated: a claim raised by a community regarding its identity shall be first presented to and treated by the council of the regional state in which the community is found. It should only be referred to the HoF if the claimant community complains that its question has not been treated by the regional council properly or in accordance with the constitution and there arises, as a result, a misunderstanding between the regional council and the community. In this case, the decision by the House of the Federation shall be final. HoF decision on the Silte case, supra note 44, p. 4.

${ }^{48}$ HoF decision on the Silte case, supra note 44, p. 4.

${ }^{49} \mathrm{CCI}$ advisory opinion, supra note 45 , p. 45 ; the opinion of the minority members of the CCI held that a referendum is not always a necessity and the regional council can decide on the ultimate fate of an identity question short of holding a referendum through other democratic mechanisms provided in the constitution. In fact, at one point, they clearly argued that it is only for cases of secession and formation of new regions that the constitution stipulates for holding of a referendum. However, they failed to clearly indicate which of these mechanisms are available in the constitution and how they can be utilized. CCI advisory opinion, supra note 44, pp. 47-48.

${ }^{50} \mathrm{HoF}$ decision on the Silte case, supra note 45, p. 5; initially the constitutional and regional affairs standing committee suggested a maximum of six months. The House of the Federation of the Federal Democratic Republic of Ethiopia (2008) "Advisory opinion of the constitutional and regional affairs standing committee", Journal of Constitutional 
The HoF decision also indicated that a detailed law on these procedural matters, whenever necessary, might be promulgated at the federal and regional levels. ${ }^{51}$ It seems that Proclamation No. 251/2001 (Consolidation of the House of Federation and the Definition of its Powers and Responsibilities Proclamation), and Proclamation No. 60/2003 (a regional Proclamation of the SNNP region, i.e., - the Consolidation of House of Council of Nationalities and Definition of its Powers and Responsibilities) were promulgated to address issues of procedure.

In particular, Proclamation No. 251/2001, concerning identity questions states: after exhaustion of all state (regional) level remedies, ${ }^{52}$ "any Nation, Nationality, or People who believes that its self-identities are denied, its right of self-administration is infringed, promotion of its culture, language and history are not respected, in general its rights enshrined in the constitution are not respected or, violated for any reason, may present its application to the $[\mathrm{HoF}]$ ". ${ }^{53}$

The same proclamation changed the one year period that was stated by the $\mathrm{HoF}$ in the Silte decision, stipulating that the region concerned shall reach a decision within two years from the time it received an application for identity determination. $^{54}$ The concerned party can then, depending upon the circumstances, directly appeal to the HoF, if the application has not been decided within two years or if it is not satisfied with the decision. ${ }^{55}$ The HoF, upon receiving the appeal, shall reach a decision over the case in not more than two years. ${ }^{56}$ Accordingly, an identity question, which starts at the regional level and goes all the way to the HoF, is expected to be settled within a maximum of four years. In reality, however, the Welene application is, for example, pending

Decisions, Vol. 1, pp. 50-52. But see the discussion below in which Proc. 251/2001 extended this period to two years.

${ }^{51}$ HoF decision on the Silte case, supra note 44, p. 5.

${ }_{52}$ Proc. 251/2001, Art. 20(1).

53 Id., Art. 19(1); See also, Proc. 60/2003, art 21(3), which provides for an identical statement. In here, one notices the confusion that arises as a result of the use by the particular provisions of the term NNPs for those groups still seeking to be recognized as an NNP. The same issue was a subject of heated debate in the HoF before the House reached a decision in the Silte case. See, The House of the Federation of the Federal Democratic Republic of Ethiopia "Decision of the HoF in the Silte case" (2008) Journal of Constitutional Decisions, pp. 57-60. One can speculate in here: since it is the particular claimant/s, which ultimately decides on whether it is an NNP or not, the drafters of the law chose to use the wording NNP rather than community or group.

${ }^{54}$ Proc. 251/2001, Art 20(2).

55 Id., Art. 20(3).

${ }^{56}$ Id., Art. 22. 
before the $\mathrm{CoN}$ and $\mathrm{HoF}$ (on appeal) ${ }^{57}$ for decades. The time limit does not thus seem to create any accountability on the institutions reviewing identity determination cases. 58

Regarding the form of the application, first, it has to be presented in writing. Second, the application must include the details of the question supported with names, addresses and signatures of at least five per cent of the inhabitants of the claimant group and whenever necessary, it should bear the official seal and signature of the administration that presented the question. ${ }^{59}$ If the application is being submitted through a delegated individual or individuals, they shall produce reliable evidence of their delegation. ${ }^{60}$

Ambiguities still persist on the type of evidence that should be submitted to substantiate that the delegates are genuine representatives of the community concerned. Other ambiguities evoke questions such as: what does the five percent threshold refer to? Does it refer to the whole claimant community or only those who support the claim? How is their signature verified for authenticity? These gaps can be exploited, both by government authorities and ethnic entrepreneurs.

\subsection{Self-determination claims}

Three aspects of SD are discussed in the following paragraphs. Establishing ethnic territorial homelands below the regional level as a means of advancing self-rule (3.2.1), territorial re-demarcations so that an ethnic group (found on the 'wrong side' of the territorial and political border) reunites with its ethnic homeland (kin) in order to best utilize the various aspects of SD (3.2.2), and the right of ethnic groups to have equitable and effective participation in various governance levels in the territories they occupy (3.2.3). The general framework for SD is found in the FDRE Constitution. In particular, Article 39 enumerates the various aspects of SD. For the most part, this provision is simulated under Article 39 of the SNNP Constitution. Of course, the SNNP Revised Constitution, while putting SD in a regional context, goes further and stipulates for ethnic based local governments.

${ }^{57}$ Application of the Welene community to the HoF, (10/07/99), document on file with the registrar of the CoN, Hawassa.

${ }^{58}$ Interview with the Speaker of the Council of Nationalities, supra note 30; Interview with Nationalities Rights Protection and Constitutional Awareness Creation Core Work Process Owner, (Hawassa, 1 July 2017). At the time of fieldwork, a task force was being setup by the CoN to formally study the petitions of the Wolanes.

59 Proc. 251/2001, Art. 21(1); Proc. 60/2003 under Art. 22(1) provides for a similar undertaking.

${ }^{60}$ Proc. 251/2001, Art, 21(2). 


\subsubsection{Questions of administrative hierarchy}

The tremendous diversity in the SNNP region, to an arguable extent, is being managed, among others, by establishing an administrative hierarchy below the regional level -known as zones and liyu weredas- targeting the accommodation of the hitherto marginalized ethnic minorities. ${ }^{61}$ The pressing question here is: what are the standard criteria for an ethnic group to have a zone or liyu wereda? Who has the authority to decide on the establishment, breakup and merger of zones or liyu weredas? What are the procedural requirements that have to be followed to request a zone or liyu wereda?

The frequently cited provisions understood to provide a not so clear constitutional base for local governments in Ethiopia are Articles 39(3) and $50(4)$ of the federal Constitution. ${ }^{62}$ Following this and in its fitting use of its subnational constitutional space, the SNNP region has established ethnic based local governments ${ }^{63}$ functioning just below the regional hierarchy. According to the FDRE Constitution, each NNP of the region is granted the right to "administer its affairs within its own defined territory" 64 as well as "establish[ing] its own governmental organizations pertinent to its geographical settlement" ${ }^{65}$ From this, it seems, the sole requirement for one to have a zone or liyu wereda is to be a recognized NNP within the region. ${ }^{66}$ Thus, all the 56 native identities, in theory, have the right to establish ethnic-based local governments provided they comply with the procedural requirements for seeking an administrative hierarchy. ${ }^{67}$

${ }^{61}$ Even though there are additional administrative hierarchies below the regional level, it is only the zones and liyu woredas that are established with the purpose of ethnic minority accommodation. A look at the provisions of Arts 80-87 of the SNNP Constitution reveals that a zone and a liyu woreda have the same institutional hierarchies. Nevertheless, in practice, it seems, a zone is allocated to ethnic groups with large population size while liyu woredas for those with small population size.

${ }^{62}$ As argued by many, the exact place of local governments in the Ethiopian discourse is not clear and straightforward. See for instance, Getachew Assefa (2015). "The Legal Framework of Local Governments in Ethiopia: Some Issues" in Asnake Kefale and Assefa Fiseha (eds) Federalism and Local Government in Ethiopia, Center for Federal Studies: Addis Ababa University, pp.188-189, Zemelak Ayele (2015). "Local Government and its Institutional Security Within Ethiopia's Federal System" in Asnake Kefale and Assefa Fiseha (eds) Federalism and Local Government in Ethiopia, Center for Federal Studies: Addis Ababa University, p. 205.

${ }^{63}$ See the SNNP Constitution, Art 39.

${ }^{64}$ Id., Art. 39(2).

${ }^{65}$ Id., Art. 39(3)

${ }^{66}$ As will be discussed under sections three and four, the practice seems to deviate from this, and focuses exclusively on administrative efficiency in granting an administrative hierarchy.

${ }^{67}$ See for instance Art $45(2)$ of the SNNP Constitution. 
From the cumulative reading of the provisions of Proclamation No. 251/2001 and Proclamation No. 60/2003, the form of presenting the application regarding question of administrative hierarchy is similar to that of question of identity: i.e., it should be made in writing, approved by at least five percent of the claimants through their signatures, and it should bear an official seal and signature of the authority presenting the question as the case may be ${ }^{68}$ Obviously, in the case of the former, the claimants are either the NNPs themselves or the concerned administrative authority representing the particular NNP. ${ }^{69}$ The same time limit of two years at both the regional and federal levels applies to questions of administrative hierarchy as well.

The various provisions of the regional constitution pertaining to the powers of the Council of Nationalities $(\mathrm{CoN})^{70}$ and the state council show who has the power to decide on the establishment, breakup and merger of the zones and liyu weredas. The SNNP Constitution stipulates that the administrative hierarchies below the regional level are the zones or liyu weredas, weredas, and Kebeles (the lowest administrative unit below the district). ${ }^{71}$ Establishing additional administrative hierarchies by taking into account the size of the population and socio-economic activities within the region is the power of the state council. ${ }^{72}$ The CoN is empowered to decide on issues relating to NNPs right to zone or liyu wereda administration. ${ }^{73}$ The $\mathrm{CoN}$ is also entrusted with the task of finding solutions to disputes that may arise between administrative hierarchies. ${ }^{74}$

It is discernible from the foregoing that, even though both have, what seems to be, an overlapping power regarding the zones or liyu weredas, their particular competencies depend on the questions raised -particularly, on who wants to do what regarding the zones or liyu weredas. A request to establish, merge or partition an administrative hierarchy for the reason of population size or for socio-economic reasons will be handled by the state council; and if the establishment, breakup or merger of the administrative hierarchy is in one way or the other related with the ethnic rights of the NNPs, it will be the exclusive jurisdiction of the $\mathrm{CoN}$.

\footnotetext{
${ }^{68}$ Proc. 251/2001, Art 21 cumulative Proc. 60/2003, Art 22.

${ }^{69}$ See Proc. 60/2003, Art 21(1) and (2) respectively.

${ }^{70}$ The CoN is the second house of parliament of the SNNP region, composed of the 56 NNPs, which among others is entrusted with the power to interpret the regional constitution. (See, Art. 59(1) of the SNNP Constitution.)

${ }^{71}$ See, the SNNP Constitution, Art 45(1). By the same provision, the state council is empowered to "organize other administrative hierarchies and determine their powers and duties".

${ }^{72}$ See, the SNNP Constitution, Art. 51(3) (b).

${ }^{73}$ Id., Art. 59(3).

${ }^{74}$ Id., Art. 59(5).
} 
The overlapping nature of the powers of the two institutions is demonstrated by the following two cases. For instance, the two dominant groups of Gamo and Gofa, in Gamo-Gofa zone have for long petitioned to the CoN for the dismantling of the union and the formation of an ethnic administration of their own. While Gamo ${ }^{75}$ feel that a separate administration of their own is justified based on their very large population size, $\mathrm{Gofa}^{76}$ in contrast claim that they have been politically dominated and marginalized by Gamos. Despite the long overdue claim, the state council was the one, which recently decided in favor of breaking up the zone and establish a Gamo zone and Gofa zone for each ethnic group, on what, apparently, looked like an ethnic based demand.

On another instance, it was the state council, which decided on the merger of the four liyu weredas to establish the Segene zone, whereas the quest of the Konso to breakaway from the same zone and establish a distinct ethnic territorial administration of its own was first handled by the $\mathrm{CoN}$ and later by the state council. The creation of the Segene zone was accomplished through the merger of the four liyu weredas (of Konso, Derashe, ${ }^{77}$ Amaro (kore), and Burji) and one regular wereda of Alle. Eight ethnic groups ${ }^{78}$ are considered as the founding members of the zone. The way in which these administrative hierarchies were amalgamated and the impact they had on the self-rule rights of the constituent ethnic groups raised eyebrows -in particular on those who used to have their own distinct ethnic territorial administrations. Among those whose liyu wereda status was revoked, the Konso case evoked much anger and the ensuing standoff led to the loss of many lives and destruction of property. ${ }^{79}$

While the regional government insisted that the decision for the consolidation was taken to curb the constant conflicts that arise between the different ethnic groups of the area, ${ }^{80}$ some contend that the move was a hasty solution to the

${ }^{75}$ The petition by the Gofa to the CoN, (24/8/98 E.C), on file with the registrar of the CoN, Hawassa; Gofas started to petition for a separate zonal status as early as 1987 E.C.

${ }^{76}$ The Gamo application to the State Council of the SNNP, (Hamle 101997 E.C), on file with the registrar of the CoN, Hawassa.

${ }^{77}$ Derashe woreda is understood to institutionally belong to the Derashe, Kusume, Mosiye, and Mashole ethnic groups.

${ }^{78}$ The eight ethnic groups considered the founding members and hence indigenous to the zone are Kore, Mashole, Mosiye, Derashe, Alle, Kusume, Burji, and Konso.

${ }^{79}$ See "Ethiopia's Clampdown on Dissent Tests Ethnic Federal Structure" (2016). The Guardian <http://www.theguardian.com/global-development/2016/apr/08/ethiopiaclampdown-dissent-ethnic-federal-structure> (last accessed 19 April 2016).

${ }^{80}$ Decision of the CoN on a request by Konso for a zonal status, Sene 20, 2008, Hawassa, p. 5 , document on file; See also the Decision of the state council to establish the Segene Area People, Yekatit 16 2003, p. 2, document on file. 
recurring quest of the Alle for self-administration and autonomy. ${ }^{81}$ Subsequently, the regional government assigned a regular wereda to Alle from territories (kebeles), which were previously administered by the Derashe and Konso liyu weredas. ${ }^{82}$ Yet, Alle regular wereda had no linking administrative tier below the regional government; and as a regular wereda, it could not have a straight connection with the regional administration. The solution pursued by the regional government was to merge the four liyu weredas along with the regular wereda of Alle and form the Segene zone. ${ }^{83}$

The apparent quick fix triggered a wide scale protest by Konsos. Soon after the establishment of the Segene zone, Konsos started petitioning to establish their own zone. They claimed that the merger undermined, among others, their self-administration rights. ${ }^{84}$ After a protracted period of petitioning, which witnessed a massive scale uprising, violence and loss of life in the konso wereda, ${ }^{85}$ the CoN decision found Konsos as not having a sufficient case for a separate zone. ${ }^{86}$

In justifying its decision, the $\mathrm{CoN}$, among others, mentioned the breakdown of the constitutional and legal order in the area, and the societal backlash against those who did not support the petition to establish a zone for Konsos. ${ }^{87}$ The CoN decided to use these two post-petition scenarios to validate the denial of the zonal request. Even though these incidents are somehow related to the petitioning process (not to mention the fact that the decision of the $\mathrm{CoN}$ was unduly delayed), using the chaos that ensued afterwards to retrospectively rationalize the establishment of the Segene zone and deny the right of Konso to self-administration did not seem a step in the right direction.

${ }^{81}$ See Applications of the Alle to the CoN (3/9/1997 E.C), (20/01/1998 E.C), (14/03/2002 E.C), on file with the registrar of the CoN, Hawassa; See the Application by Alle (Debase Gewada) to HoF (23/10/98 E.C), on file with the registrar of the HoF, Addis Ababa.

${ }^{82}$ Abate Seyoum (2017). "What was troubling Konso? How Konso people's demand for constitutional self-determination was met with state violence" Addis Standard <http://addisstandard.com/commentary-what-was-troubling-konso/> (last accessed on July $28,2017)$.

${ }^{83}$ Ibid.

${ }^{84}$ See the latest applications by Konso to the CoN, (Sene 13, 2008 E.C), (13/02/2007 E.C) on file with the registrar of the CoN, Hawassa; Application by Konso to the HoF, (20/01/2008 E.C), on file with the registrar of the HoF, Addis Ababa.

${ }^{85}$ See for instance "The Konso Face Escalating Torture, Killings and Human Rights Violations Following their Constitution-based and Peaceful Request for Zone Administrative Structure".

<http://konsopeople.com/protest-\%E1\%89\%B5\%E1\%8C\%8D\%E1\%88\%8D/> (Last accessed on 28 July 2017).

${ }^{86}$ Decision of the CoN on Konso, supra note 80, pp. 1-9.

${ }^{87}$ Id., pp. 3-5. 
The CoN further argued that the amalgamation of the administrative hierarchies was undertaken to boost economic development and eradicate conflicts. The decision however fails to justify how the recentralization process can achieve this or why this cannot be accomplished if Konso remained as a liyu wereda or if they separate to establish their own zone. The CoN seems to believe that the merger has not affected the self-rule rights of ethnic groups in the zone, since those ethnic groups continue to exercise self-administration through their respective (regular) weredas. ${ }^{88}$ A simple look at the provisions of the SNNP Constitution on regular weredas and liyu wereda or zones clarifies their difference. ${ }^{89}$ While the latter is an administrative hierarchy having the purpose of ethnic minority accommodation, the former is simply a hierarchy set up for administrative decentralization without the purpose of catering to the needs of ethnic self-rule demands. ${ }^{90}$

The $\mathrm{CoN}$ reasoned that a request for additional administrative hierarchies has to be seen in light of whether such requests benefit the people or not because an administrative hierarchy is not an end in itself. ${ }^{91}$ A question that arises in response to this argument is whether this was not clear from the outset in establishing the region and the ethnic federal structure in general. The decision of the CoN in this regard cannot be explained in light of Article 39 of the SNNP Constitution, which declares that all NNPs have the right to establish ethnic based local governments. Without having clear guidelines on how to establish, breakup or merge administrative hierarchies, the crude reasoning of administrative efficiency seems more of a double standard rather than a reasonable justification.

In spite of the claim that the administrative integration has been beneficial to ethnic groups that are better off from their previous positions, ethnic antagonisms still continue to bedevil the sub-regional administration. ${ }^{92}$ After all

${ }^{88}$ Decision of the CoN on Konso, supra note 80, p. 7; A similar understanding existed when the merger was decide by the State Council, Decision of the CoN on Konso, supra note 80, p. 3.

${ }^{89}$ Compare Arts 80-89 on zone or liyu woreda administrations to that of Arts 90-102 on woreda administrations of the SNNP Constitution.

90 Despite the constitution establishing woredas as mere administrative units of decentralization, there appears a confusion of considering these woredas as serving a similar purpose of ethnic minority accommodation. If any, the only time these woredas are constitutionally empowered to cater to ethnic identity issues is, as per article 58(3), where an ethnic groups does not have a liyu woreda or zone, the woreda council is used to elect a representative of that particular ethnic group to the $\mathrm{CoN}$.

${ }^{91}$ Decision of the CoN on Konso, supra note 80, p. 6.

${ }^{92}$ For instance, see the application by the Kore (Amaro) minority found in Burji woreda to the CoN, (15/05/2006 E.C), on file with the registrar of the CoN, Hawassa, in which they allege that Kore ethnic minorities living in the Burji woreda are discriminated against and 
this process, it was recently decided, apparently overturning the decision of the CoN, that Konso should be established as a separate zone. ${ }^{93}$ And surprisingly, the decision was made not by the CoN but by the state council.

One can cautiously argue, since the question of merger (administrative integration) by the four liyu weredas was made on the basis of enhancing administrative efficiency, it was handled by the state council, as it was thought it had nothing to do with ethnic rights. However, the Konso question to establish its own zone, exclusively pleaded that the administrative integration has tampered with the right to self-rule of Konso; the decisions of the CoN and the state council, further blur the respective competencies between the $\mathrm{CoN}$ and the state council when it comes to an ethnic group's demand for self-rule and territorial autonomy (TA).

Looking at the rules of decision-making, the state council supposedly decides on questions of administrative hierarchy (that are short of ethnic claims), on the basis of votes cast by members of the state council. ${ }^{94}$ However, the regional constitution does not provide for specific substantive rules which can be the basis for the council to reach at a decision. The $\mathrm{CoN}$, on the other hand, is required to resolve issues of administrative hierarchy (centered on ethnic rights) based on "settlement pattern, languages, identities, and consent of the people concerned. ${ }^{.95}$ In spite of this, the issue of administrative hierarchy -depending up on how the question is raised- shall ultimately be decided by the NNP concerned through a majority vote ${ }^{96}$ or by the council (concerned) supported by two third of its members. ${ }^{97}$ The CoN, in settling this matter, shall only take a maximum of one and a half years. ${ }^{98}$

in particular they have been denied of, among others, the right to have their children taught in their own mother tongue.

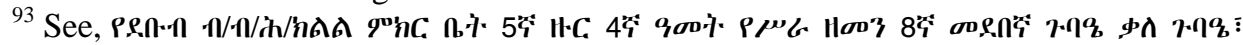
document on file.

${ }^{94}$ Concerning decision making procedures at the state council level, see art 56(1) and (2) of the SNNP constitution.

${ }^{95}$ Proc 60/2003, Art 21(2).

${ }^{96}$ Id., Art. 23(1).

${ }^{97}$ Id., Art. 23(2).

${ }^{98}$ Id., Art. 23(3). 


\subsubsection{Boundary re-demarcations as a mechanism of responding to self- determination claims}

Regardless of the various ways boundaries might be drawn, territorialization in a federal setup will always leave some ethnic groups "on the wrong side". ${ }^{99}$ Even though the underlying purpose of creating ethnic homelands is to construct a political community within a particular territory whereby that community articulates its wishes through self-rule, while at the same time participating in the wider context through shared rule, ${ }^{100}$ no territorial unit can be hundred percent homogenous. Under such circumstances, the fear is, minorities turned majorities will use their new gained powers to oppress and discriminate against their own minorities..$^{101}$

The SNNP region is not an exception to this challenge. Various ethnic disputes have erupted revolving around border areas between ethnic groups. ${ }^{102}$ As a solution to the problem, boundary demarcations and re-demarcations have occurred. In the context of the SNNP region, redrawing of boundaries mainly refers to: (i) redrawing the regional boundary with other neighboring regions, and (ii) redrawing (or request to re-draw) internal boundaries to resolve a dispute between ethnic groups in two sub-regional administrations (zones or liyu woredas).

While it is the exclusive power of the HoF to resolve boundary disputes between two regions, ${ }^{103}$ it is the power of the $\mathrm{CoN}$ to settle boundary disputes between two sub-regional administrations. ${ }^{104}$ The $\mathrm{CoN}$ is required to settle such disputes in not more than one and a half years from the receipt of an application. ${ }^{105}$ It shall decide on these (internal) border disputes on the basis of the peoples' consent and settlement patterns. ${ }^{106}$ Accordingly, it can settle the matter either by out rightly passing a decision, if it thinks it has sufficient

${ }^{99}$ Michael Keating (2004). "So Many Nations So Few States: Territory and Nationalism in the Global Era" in AG Gagnon and J Tully (eds) Multinational Democracies, Cambridge University Press, p. 45.

${ }^{100}$ Annelies Verstichel (2009). Participation, Representation and Identity: The Right of Persons Belonging to Minorities to Effective Participation in Public Affairs: Content, Justification and Limits, Intersentia, p. 469.

${ }^{101}$ Margaret Moore (2005). "Internal minorities and Indigenous Self-determination" in A Eisenberg and J Spinner-Halev (eds) Minorities within Minorities: Equality, Rights and Diversity, Cambridge University Press, p. 272.

102 The prominent one in this respect is the border dispute between Wolayita and Sidama zones in and around lake Abaya. See, Aalen, supra note 11, pp. 163-171.

${ }^{103}$ See, the FDRE Constitution, Art. 62(6).

${ }^{104}$ See, the SNNP Constitution, Art 59(5).

${ }^{105}$ Proc. 60/2003, Art 36.

${ }^{106}$ Id., Art. 32. 
information on the matter ${ }^{107}$ or organizing a referendum, if it finds it difficult to assess the consent of the people. ${ }^{108}$

An instance of the former case is the decision of the $\mathrm{CoN}$ in an internal border dispute in Lake Abaya area between Sidama and Wolayta zones. ${ }^{109}$ The Abaya area is a locality found between Humbo woreda of Wolayita zone and Dale woreda of Sidama zone. In eight of the Kebeles, Sidama submitted application for demarcation from Humbo woreda to Dale woreda of Sidama zone. The CoN gave a decision accepting the demands of the Sidama and decided that they should be re-demarcated into the Dale woreda ${ }^{110}$ Wolayita lodged an appeal to the HoF against this decision. ${ }^{111}$ However, the HoF affirmed the decision of the CoN. Nevertheless, to date, no border demarcation has taken place based on the decision of the two institutions. ${ }^{112}$

Wolayita thought that the decision went in favour of the Sidama because of the latter's political dominance within the region. ${ }^{113}$ In contrast, Sidama communities in the area thought the only way to secure their existence is demarcation to the Sidama Zone. ${ }^{114}$ After the recent conflict between Sidama and Wolayita, the Abaya dispute has resurfaced and each group is strengthening its claim over the disputed territory.

\subsubsection{Equitable and effective participation ${ }^{115}$}

In spite of the claim that ethnic groups are entitled to administer their own affairs in their own defined territories, the reality (in a region that hosts 56 ethnic groups) shows that only few ethnic groups have sub-regional administrations of their own. Furthermore, territorial administrations exhibit ethnic heterogeneity rather than homogeneity. As a result, those entitled to territorial autonomy became the titular groups that threaten the individual and group specific rights of

${ }^{107}$ Id., Art. 33(1).

${ }^{108}$ Id., Art. 33(2).

${ }^{109}$ See the Decision of the CoN Regarding the Border Demarcation Dispute in Abaya area between the Humbo woreda of Wolayita Zone and Dale woreda of Sidama zone (Butajira 14 Nehase 1997 E.C), document on file.

${ }^{110}$ Ibid.

${ }^{111}$ Application of Wolayitas in Humbo Woreda to the HoF, (Meskerem 12, 1998 E.C), copy on file with the registrar of the HoF, Addis Ababa.

${ }^{112}$ Interview with Head of the Constitutional Matters Core Process, Council of Nationalities (Hawassa, 8 February 2016).

113 Aalen, supra note 11, p. 175.

${ }^{114}$ Id., p. 173.

115 The discussion of equitable participation is only limited to administrative hierarches (zones or liyu woredas) that are created to accommodate ethnic minorities. 
the non-titular ones. ${ }^{116}$ The puzzling question, therefore, is: how can the nontitular groups be entitled to exercise their right of equitable and effective participation at the regional level and sub-regional territorial administrations? ${ }^{117}$

As some cases like the Qebenas ${ }^{118}$ in the Gurage zone demonstrate, a petition for a territorial administration is triggered by lack of effective and equitable participation. Qebenas justify their request for a liyu wereda primarily by asserting that they suffer from discrimination from the zone in the distribution of resources, lack of infrastructure, unemployment, absence of good governance. ${ }^{119}$ They allege that a liyu wereda of their own will allow them to get fair representation in all levels of government structure since the zone has promoted the supremacy of the Gurage identity alone. ${ }^{120}$

More recently, the lack of participation has also led to a boundary dispute between the Welkite city administration (the capital of Gurage zone) and Qebena wereda. Qebenas allege the city administrations territorial expansion is being undertaken at the expense of their self-rule rights. ${ }^{121}$ Obviously, an elevation of Qebenas to a liyu wereda will automatically put on hold any expansion to the territory they claim as theirs, since liyu weredas, unlike regular weredas, have their own defined territories in the interest of promoting the self-rule rights of a particular ethnic group. ${ }^{122}$ A similar claim by Kara found in Hamer wereda of South Omo has been submitted to the CoN claiming that Kara have been politically underrepresented in the wereda and zone administration structures. ${ }^{123}$ In view of this, how should these claims be addressed?

Article 39(3) of the FDRE Constitution seems to provide a starting ground for equitable representation. ${ }^{124}$ In light of this, how is the issue of equitable and effective participation being addressed in the SNNP region? Three points are worth mentioning in order to understand the region's approach to the dilemma.

\footnotetext{
${ }^{116}$ Asnake, supra note 15, p. 6.

${ }^{117}$ See, the FDRE Constitution, Art 39(3).

${ }^{118}$ Qebena are one of the native identities recognized in the Gurage zone along with Gurage and Mareko.

${ }^{119}$ See the application by Qebena to the CoN, (10/12/1997 E.C), on file with the registrar of the CoN, Hawassa; See the application by Qebenas to the SNNP State Council, (30/05/06E.C), on file with the registrar of the CoN, Hawassa.

${ }^{120}$ See the application by Qebena to the CoN, (10/12/1997 E.C), (3/10/2001E.C.), on file with the registrar of the CoN, Hawassa.

${ }^{121}$ See the application by Qebena to the CoN, (10/09/06 E.C), (16/05/08) on file with the registrar of the CoN, Hawassa.

${ }^{122}$ See the SNNP Constitution, Art. 91(2).

${ }^{123}$ Application submitted by Kara to the CoN, (22/08/2004 E.C), on file with the registrar of the CoN, Hawassa.

${ }^{124}$ Arts 39(3) of the SNNP Constitution provides for a similar right.
} 
The first dilemma relates to ethnic groups to whom it was possible to grant and establish territorial autonomy, zones and liyu weredas. To an arguable extent, their demand to have effective participation, not only at the regional level, but also at the sub-regional levels seems to have been satisfied. Despite this, however, these sub-regional administrations have not been able to contain the quest for additional zones or liyu weredas and equitable representation within the sub-regional administrations themselves. ${ }^{125}$

The second dilemma is the impossibility of ensuring territorial autonomy (TA) to all ethnic groups of the region ${ }^{126}$ as a result of which the CoN was established. All the 56 native identities are represented in $\mathrm{CoN}^{127}$ perhaps to counter the demand of every ethnic group for its own territory. ${ }^{128}$ The CoN (being a House composed of the region's NNPs) was given important powers such as regulating disputes between the various ethnic groups, quest for administrative hierarchies and border disputes (between sub-regional administrations) ${ }^{129}$ This, in some way, is assumed to have given decisionmaking powers to all NNPs of the region so that they can take matters into their own hands. ${ }^{130}$

The third dilemma is related with equitable representation although the region has arguably, ensured that the native identities are represented at the regional council. ${ }^{131}$ It is assumed that the representation of the NNPs has been guaranteed to enable them to take authority of what is going on at the regional level. But the concept of equitable representation in the region seems to be challenged by issues of both constitutional design and political practice.

In terms of constitutional design, ethnic diversity is more pronounced in SNNP regional state than any of the other regions; and thus the adoption of majoritarian decision-making procedures at the $\mathrm{CoN}$ and regional council ${ }^{132}$ does not match, in particular, to the quest of ethnic minorities for effective

\footnotetext{
${ }^{125}$ See the discussions under section three below. One can see the claims of the Qebena and Mareko in the Gurage zone and Kara in the South-Omo Zone.

${ }^{126}$ See Aalen, supra note 15, p. 101.

${ }^{127}$ See, the SNNP Constitution, Art. 58. The rule of representation is: more populous groups will have the higher number of representatives in the council. In spite of this, an ethnic group, no matter how small it might be, is at least guaranteed a seat.

${ }_{128}$ In fact one of the important powers of the CoN, as per Art 59(4) of the SNNP constitution, is to "promote/and consolidate the unity and equality of the peoples of the region".

${ }^{129}$ See, the SNNP Constitution, Art. 59.

${ }^{130}$ Aalen, supra note 11, pp. 101-102.

${ }^{131}$ See for instance the ethnic composition of the representatives of the SNNP regional Council, fifth Round General Election (2015-2020), document on file.

${ }^{132}$ See Arts 60 and 56 respectively of the SNNP Constitution.
} 
participation. It is to be noted that the electoral system of first-past-the-post (that was used to elect members of the regional council) makes the representation of ethnic minorities difficult where electoral constituencies are established on ethnic basis. ${ }^{133}$ Moreover, the use of a language proficiency requirement for political candidature puts additional barriers for equitable representation, if any, for ethnic minorities living outside of their designated ethnic territories. ${ }^{134}$

Looking at the political practice, the region that is being overwhelmingly ruled by the Southern Ethiopian Peoples Democratic Movement (SEPDM) -the region's ruling party since its inception- does not and cannot seem to operate outside of the wishes of the party. A strong caveat has to be put for this statement. The portrayal of the days considering EPRDF and SEPDM -one of its constituent members- as ones which exhibit strong party discipline with centralist decision-making tendencies seems to be long gone. Especially, after strong anti-government social movements that shook the country-since September 2015- the core nature of EPRDF and thereby SEPDM have been significantly altered. Yet, one can argue that the party's firmly held priority of administrative integration within the region has undermined the desire by ethnic groups for additional zones and liyu weredas. ${ }^{135}$

However, recent developments reveal that the region seems to be heading towards an all out administrative disintegration. SEPDM has already approved the demand by Sidama for a separate regional status and the additional establishment of ethnically based sub-regional administrations. ${ }^{136}$ While many ethnic groups have followed suit and requested for the establishment of either their own separate region or territorial administration, ${ }^{137}$ the region stands at crossroads between respecting and implementing the constitutional promises on accommodation of diversity, on the one hand and the desire to avoid ethnic and territorial fragmentations, on the other.

\section{Between Rhetoric and Practice: In Search of Middle Ground?}

In view of the various petitions, the pressing issue is, whether rhetoric (constitutional promises) are put into practice. And above all, how can the everincreasing demands for identity recognition and SD claims be reconciled with

\footnotetext{
${ }^{133}$ For more on the electoral system, see, Beza Dessalegn "The Right of Minorities to Political Participation under the Ethiopian Electoral system" (2013) 7/1 Mizan Law Review 67 at $67-100$.

${ }^{134}$ ZeMelak Ayele (2012). "Decentralization, Development and Accommodation of Ethnic Minorities: The Case of Ethiopia" (PhD Thesis, University of the Western Cape) p. 467.

${ }^{135}$ See the discussion below under section three.

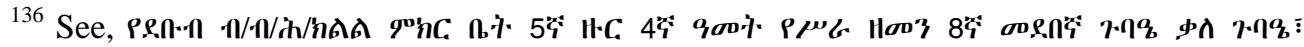
document on file.

${ }^{137}$ Ibid.
} 
the threats of territorial and ethnic fragmentations. The Silte case, which relied on the definition of ethnic groups under Article 39(5), is, arguably, the closest that came to understanding and responding to claims for recognizing separate identities. It is difficult to argue that this provision was initially intended to respond to these kinds of demands. There appears no indication including in the preparatory document of the FDRE Constitution that the drafters foresaw a problem of this nature and included a constitutional remedy for it.

With respect to SD claims, Article 39 of both the FDRE Constitution and SNNP Constitution, state that NNPs have the right to administer themselves within a defined territory. And no clawback clause, like administrative efficiency, is found in these constitutions, or in other subordinate legislations. ${ }^{138}$ If so, what can we make of the decision of the CoN to deny the Konso zonal request on the basis of administrative efficacy? Of course, there is a need to balance between the right of NNPs to preserve their identity and establish institutions of self-rule with that of ethnic and territorial fragmentations. But, that should not be done at the expense of undermining the identity and SD rights of ethnic groups.

The political practice seems very clear in this regard. The federal government has several times unequivocally stated that all ethnic based questions have been constitutionally answered -what remains is simply rent-seeking local elites trying to exploit the masses for their personal gains. ${ }^{139}$ The ruling party of the SNNP region has previously made its policy clear on questions of administrative hierarchy. As Aalen noted:

"requests for new zone or special wereda administrations would ... be considered from a purely administrative perspective, ... clearly separated from the right of the nationalities to self-determination. Groups could no longer simply argue that recognition of a separate ethnic identity automatically gave them the right to a separate administration". ${ }^{140}$

${ }^{138}$ Some countries have put number as a standard criterion to establish institutions of minority protection. For instance, to establish non-territorial autonomy councils in Estonia, the number of the concerned minority group seeking autonomy should be more than 3000. See, David J. Smith (2013) "Non-Territorial Autonomy and Political Community in Contemporary Central and Eastern Europe" Journal on Ethnopolitics and Minority Issues in Europe Vol. 12 No. 1, p. 39.

${ }^{139}$ Former Prime minister Hailemariam Desalegn made this very clear in a speech he made to various academicians who came from various universities, (broadcast by Ethiopian Broadcasting Corporation 15 March 2016). The current Prime Minister, Abiy Ahmed, the authors' feel, is yet to clearly articulate his and the party's position regarding ethnic based demands.

${ }^{140}$ Aalen, supra note 11, p. 106; See also Interview with Speaker of the Council of Nationalities, supra note 30. 
With respect to equitable participation in the region, regardless of the stipulations under the federal and SNNP constitutions, the notion of ethnic ownership of territory and its government institutions by the titular ethnic groups does not seem to fade anytime soon. In fact, the problem is that the titular group has no incentive to share its privileges with the non-titular group. For those territorially concentrated ethnic minorities found bordering their ethnic kin and denied of equitable participation, petitioning for territorial re-demarcations seem the only solution so far. There appears no available political solution to territorially dispersed ethnic minorities.

The HoF and CoN do not seem to take into account the various time limits in settling the claims irrespective of the claims presented although some of these claims are as old as the federal arrangement. In fact, they seem to be managing most of the petitions by not responding. The time limits provided by the various laws have simply fallen into oblivion and have also not helped in holding these institutions accountable.

There is indeed the need to examine measures that can or should be taken to tackle the dilemma of reconciling the tension between fragmenting identities and territory with the desire for maintaining territorial and ethnic unity. Perhaps, one mechanism of responding to ethnic based demands, especially in circumstances of extreme ethnic plurality, is to separate ethnic rights from territorial claims. The respect and protection of ethnic based demands does not necessarily have to be dealt by the granting of territorial autonomy alone.

Hence, the recognition of ethnic identity should not automatically mean ethnic autonomy. This primarily avoids the territorialization of ethnicities. The setback, however, is: this is in direct disagreement with what the FDRE Constitution says about ethnic rights -that ethnic groups have the (unrestricted) right to ethnically defined territories. While it may be necessary to qualify in the Constitution, which ethnic rights lead to territorial claims -possibly through constitutional amendment- non-territorial mechanisms of accommodating minorities should also be employed to offer legal and institutional responses to the ever-increasing claims of ethnic groups. ${ }^{141}$

Another mechanism could be the strengthening of citizenship rights, conceivably through the strict enforcement of Bill of Rights, ensuring that members of minority communities shall and will not be subjected to marginalization and second-class treatment as a result of the ethnicization of

${ }^{141}$ See for instance, Christophe Van der Beken, (2010), 'Minority Protection in Ethiopia: Unraveling and Improving Ethnic Federalism' Recht in Afrika, pp. 243-273; Beza Dessalegn (2019), "Experimenting with Non-territorial Autonomy: Indigenous Councils in Ethiopia”, Journal of Ethnopolitics and Minority issues in Europe, Vol. 18, No. 2. pp. 3-23. 
territories. ${ }^{142}$ While the respect for ethnic rights forms the cornerstone of ethnic federalism, such shall not be allowed to propagate new platforms of discrimination and undermine the rights of minorities that seek to redress past injustices with present retributions. ${ }^{143}$ The strict enforcement of Bill of Rights is understood to put to check exclusionary attitudes of dominant groups as against their minorities. By encouraging the idea of an overarching common citizenship geared towards building a common political identity, it is argued that it is possible to counter or moderate the exclusionary tendencies of ethnic empowerment and the 'politics of difference'.

Competing ethno-nationalisms, as is the case in many federations, have been mitigated with nuanced approaches of consociational power sharing between contending groups. ${ }^{144}$ This kind of power sharing has offered, arguably, some of the best institutional solutions to many ethnic conflicts. ${ }^{145}$ While regional and sub-regional units in Ethiopia are visibly heterogeneous, they have practically been treated as though they were homogenous. For what it is worse, they have been bestowed to select ethnic groups as properties, which consider them as their exclusive dominions. ${ }^{146}$ This has made it extremely difficult to implement and institutionalize any form of power sharing, as elites from dominant groups, in many circumstances, often find no incentive to share territories they consider their own. ${ }^{147}$ Despite the various rights of minority groups that are embodied in the federal and regional constitutions, one of their major limitations is the failure to institutionalize a mechanism by which "the constituent minorities could genuinely share power and be effectively represented in the institutions of the

${ }^{142}$ Yonatan Tesfaye Fessha and Christophe Van Der Beken (2013), 'Ethnic Federalism and Internal Minorities: The Legal Protection of Internal Minorities In Ethiopia', African Journal Of International And Comparative Law, Vol. 21. No. 1, pp. 41-43.

${ }^{143}$ Thomas Benedikter (2014). 'Territorial (Sub-State) Autonomy in India' in Levente Salat et al (eds) Autonomy Arrangements Around the World: A collection of Well and Lesser Known Cases, Cluj-Napoca, p. 79.

${ }^{144}$ John McGarry, Brendan O'Leary and Richard Simeon (2008). 'Integration or Accommodation? The Enduring Debate in Conflict Regulation', in Sujit Choudry (ed.)

Constitutional Design for Divided Societies: Integration or Accommodation? Oxford and New York: Oxford University Press, pp. 58-63; see also, Allison McCulloch, (2014).

Consociational Settlements in Deeply Divided Societies: The Liberal Corporate Distinction, Democratization, Vol. 21, No. 3, 501-518.

${ }^{145}$ The case of Switzerland and Belgium are instructive in this regard.

${ }^{146}$ Yonatan Fessha (2018). 'Empowerment and Exclusion: The Story of Two African Federations', in Gagnon, Alain-G and Michael Burgess (eds.) In Revisiting Unity and Diversity in Federal Countries: Changing Concepts, Reform Proposals and New Institutional Realities, Leiden/ Boston: Brill Nijhoff, pp. 60-63.

${ }^{147}$ Assefa Fiseha (2017). "Intra-Unit Minorities in the Context of Ethno-National Federation in Ethiopia”, Utrecht Law Review, Vol. 13, No. 1, p 186. 
national and, as appropriate, subnational governments respectively". ${ }^{148}$ There is ample evidence, now in Ethiopia, to show that this problem has to be addressed at a constitutional level.

Dominant ethnic groups in Ethiopia have used territorial autonomy not only to advance their rights, but also to suppress their internal minorities. This, inter alia, requires giving power to the central government to intervene when the position of internal minorities is compromised and whenever local authorities are either unable or unwilling to remedy it. ${ }^{149}$ This power of intervention should be seen distinctly from strict federal intervention or declarations of state of emergencies, which are ordered when there is a general deterioration of peace and order. Rather, the power of the central government to intervene in this case is made exclusively when regional majorities undermine the position of regional minorities. Moreover, the continuity of ethnic autonomy should also be made dependent, among others, on a satisfactory evaluation of the treatment of its minorities. The formation of new ethnic territorial arrangement has to also be contingent on the existence of sufficient legal and institutional guarantees to those that will become minorities upon the creation of the new arrangement.

\section{Conclusion}

Undoubtedly, claims to identity recognition and self determination (SD) have been a severe test, not only for the region of SNNP, but also for the overall federal dispensation. Clearly, the constitutional architecture, both at the federal and regional levels, bestows extensive space for groups to organize under distinct identities and seek separate ethnic territorial administrations. More than any other time, the manner in which identity and SD claims are to be handled in the SNNP region has become extremely sensitive. The increase or otherwise of the number of politically recognized ethnic groups and their respective ethnic territorial administrations requires cautious decisions.

The regional government's stubborn stance against identity and self determination (SD) claims has in fact made petitions for them to proliferate. Undoubtedly, these claims will continue to increase and seriously test the resilience of the Ethiopian federal structure unless the political apparatus delicately balances the constitutional rights to identity recognition and SD with that of the threat of ethnic and territorial fragmentations.

\footnotetext{
${ }^{148}$ For an in depth discussion, see Getachew Assefa, (2014). Constitutional Protection of Human and Minority Rights in Ethiopia: Myth v. Reality (PhD Thesis, University of Melbourne), pp. 79-88.

${ }^{149}$ Assefa, supra note 147, p 184.
} 